\title{
Computed tomography angiography for imaging results of neochordal mitral valve repair
}

\author{
Radosław Zwoliński ${ }^{1}$, Anna Marcinkiewicz ${ }^{1}$, Konrad Szymczyk ${ }^{2}$, Jarosław Drożdż ${ }^{3}$ Ryszard Jaszewski ${ }^{1}$, \\ Bogdan Jegier ${ }^{1}$ \\ ${ }^{1}$ Department of Cardiac Surgery, Clinical Teaching Center, Medical University of Lodz, Poland \\ 2Department of Radiology - Imaging Diagnostics, Norbert Barlicki Memorial Teaching Hospital No. 1, Medical University \\ of Lodz, Poland \\ ${ }^{3}$ Department of Cardiology, Clinical Teaching Center, Medical University of Lodz, Poland
}

Kardiochirurgia i Torakochirurgia Polska 2017; 14 (2): 89-92

\begin{abstract}
Introduction: Degenerative mitral regurgitation is currently the most frequent indication for mitral valve repair.

Aim: To visualize and assess the mid-term results of mitral valve repair with neochordae implantation, using computed tomography angiography (CTA) imaging.

Material and methods: The CTA with ECG gating and without modulation was applied in 10 patients to assess the results of a mitral valve sparing procedure. The results of 3 patients are presented. The patients were operated on for severe symptomatic degenerative mitral regurgitation, defined according to a modified Carpentier's functional classification.

Results: Neochordal repair, by placing expanded polytetrafluoroethylene sutures between the leading edge of the prolapsing segment and the corresponding papillary muscle, was conducted. From 1 to 3 double Gore-Tex loops were used. Leaflet clefts, if present, were sutured. All repairs included mitral valve ring annuloplasty. The CTA was performed at 20-24 months after the surgery. Long-axis views, reconstructed during midsystole, seemed to be the most valuable. Good quality cardiac images, precisely presenting the mitral valve complex with its constituents, were obtained in the case of patients without obesity, with a relatively small anterior-posterior thorax dimension, with sinus, slow heart rhythm and quite good left ventricle contractility. The evaluation of the mitral valve included presence of calcifications, fibrosis or thickening, chordal insertion and coaptation points, and papillary muscle locations. Primary and secondary native chordae tendineae and artificial chordae were visualized.

Conclusions: Contrast material-enhanced ECG-gated CTA applied after mitral valve repair with Gore-Tex neochordae allows one to obtain satisfactory mitral valve images, especially during mid-systole, and evaluate mid-term results of the surgery in chosen patients.
\end{abstract}

Key words: mitral regurgitation, neochordae, computed tomography angiography.

\section{Streszczenie}

Wstęp: Niedomykalność mitralna na tle zwyrodnienia stanowi obecnie najczęstsze wskazanie do plastyki zastawki mitralnej. Cel: Ocena średnio odległych wyników plastyki mitralnej za pomocą angiografii tomografii komputerowej (CTA).

Materiat i metody: Angiografia tomografii komputerowej bramkowana EKG bez modulacji została zastosowana u 10 pacjentów, z czego wyniki przedstawiono dla 3 pacjentów. Wszystkich chorych operowano z powodu ciężkiej degeneracyjnej niedomykalności mitralnej zdefiniowanej według klasyfikacji Carpentiera. Wyniki: Plastyka sztucznymi strunami ścięgnistymi pomiędzy wypadającym segmentem a odpowiadającym mięśniem brodawkowatym obejmowała użycie od 1 do 3 podwójnych loop. Dodatkowo zszyto clefty płatków, a plastykę uzupełniono wszczepieniem pierścienia. Angiografię tomografii komputerowej wykonano 20-24 miesiące po operacji. Skany w długiej osi uzyskane w środkowej fazie skurczu były najbardziej przydatne. Skany wysokiej jakości obrazujące szczegółowo zastawkę mitralną wraz z jej składowymi uzyskiwano w przypadku pacjentów bez otyłości, ze stosunkowo małym wymiarem przednio-tylnym klatki piersiowej, z wolnym, zatokowym rytmem serca oraz dobrą kurczliwością mięśnia sercowego. Ocena zastawki mitralnej obejmowała obecność zwapnień, zwłóknień i pogrubienia płatków. Oceniono ponadto miejsce wszycia sztucznych strun, kooptację płatków i położenie mięśni brodawkowatych. Zobrazowano pierwotne i wtórne struny ścięgniste oraz sztuczne nici ścięgniste.

Wnioski: Angiografia tomografii komputerowej pozwala z dobrym efektem ocenić średnio odległe wyniki plastyki zastawki mitralnej z użyciem sztucznych strun ścięgnistych w wybranej grupie pacjentów.

Słowa kluczowe: niedomykalność mitralna, struny ścięgniste, tomografia komputerowa.

Address for correspondence: Anna Marcinkiewicz MD, Department of Cardiac Surgery, Clinical Teaching Center, Medical University of Lodz, 251 Pomorska St, 92-013 Lodz, Poland, phone/fax: +48 4220144 60/61, e-mail: annamar87@o2.pl

Received: 21.03.2017, accepted: 8.05.2017. 


\section{Introduction}

Mild mitral valve insufficiency is observed in $10-30 \%$ of patients undergoing echocardiographic examination [1]. In the majority, the etiology of primary mitral insufficiency is degenerative, with myxomatous degeneration as a leading cause. Chronic myocardial ischemia is the principal mechanism triggering secondary mitral regurgitation [2]. Currently, regardless of the etiology, mitral valve repair is preferred, as it provides good long-term results [2]. Echocardiography remains a widely accessible, cost-effective and repeatable diagnostic method to evaluate heart valve diseases. Computed tomography angiography (CTA) is mainly indicated before other cardiac procedures to exclude coronary artery disease in low-risk patients. However, CTA also ensures good visualization of the normal cardiac valves, and most of the valvular pathologies [3].

\section{Aim}

We aimed to visualize and assess the mid-term results of mitral valve repair with neochordae, using CTA imaging.

\section{Material and methods}

Computed tomography angiography imaging was performed with GE Lightspeed VCT64. Acquisition parameters of CTA included collimation of $0.6 \mathrm{~mm}$, gantry rotation time of $0.36 \mathrm{~s}$, tube voltage of 100-140 kV (the parameter was slightly modified, depending on the patient's constitutional features, to increase the quality of images) and tube current of 650-770 mA. Slice thickness was $0.625 \mathrm{~mm}$, field of view $32 \mathrm{~cm}$ and scanning time 8-15 s. The injection proto-

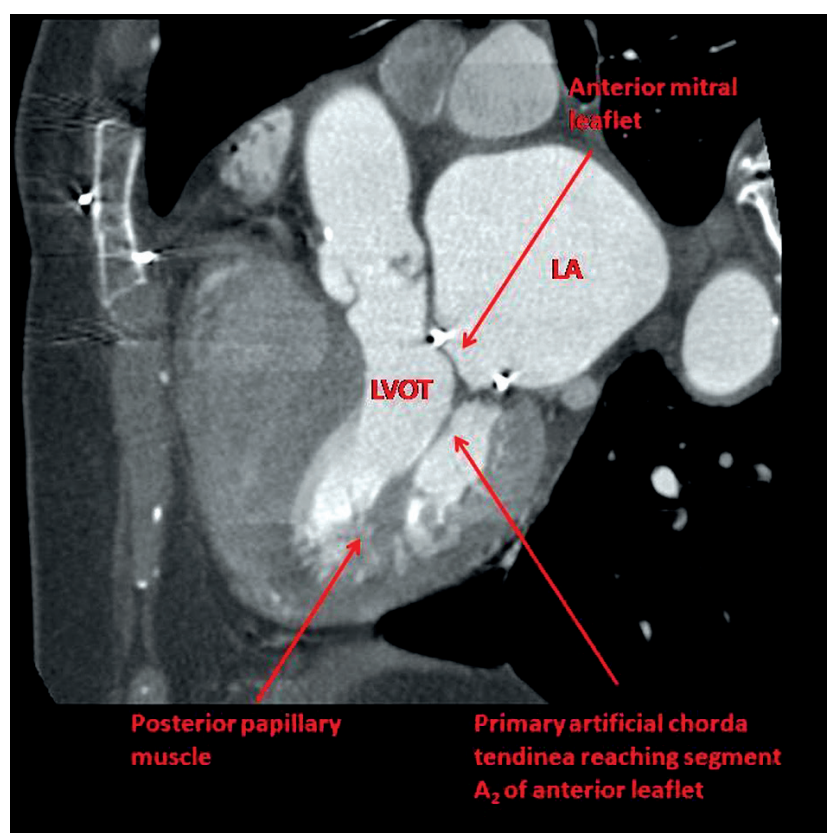

Fig. 1. Very good quality of three-chamber cardiac image providing insight into posteromedial papillary muscle with implanted GoreTex chorda tendinea. Simultaneous assessment of the aortic root can be easily performed

LA - left atrium, LVOT - left ventricle outflow tract. col included $80 \mathrm{ml}$ of contrast (lomeron 400) with an injection rate of $5.2 \mathrm{ml} / \mathrm{s}$. A $30 \mathrm{ml}$ bolus of saline solution was administered with the same injection rate. Cardiac images were acquired during breath holding in mid-inspiration. A total of 2000 slices were collected for the whole cardiac cycle. Cine and static reconstructions, including standard echocardiographic views, were performed. In the case of heart rate $>70 / \mathrm{min}$, intravenous infusion of a $\beta$-blocker was given, to improve the quality of cardiac images.

We chose 3 patients, in whom we received the most diagnostic images, to present results of CTA examination.

The first patient was a 60-year-old woman, with anterior leaflet prolapsed, caused by A2 segment chordae rupture. The left atrium $(6.1 / 5.5 \mathrm{~cm})$ and left ventricle (LV) $(6.4 / 4.1 \mathrm{~cm})$ were enlarged, but the systolic function of the LV was preserved with good ejection fraction (EF) of $64 \%$. CG Future Annuloplasty Mitral Valve Ring 28 was used and 2 double Gore-Tex loops were sutured to the prolapsing A2 segment. MAZE III ablation was also performed.

The second patient was a 61-year-old woman with persistent atrial fibrillation and mitral regurgitation classified as I, II and III, according to Carpentier's functional classification. The A2 segment chordae were ruptured, and the posterior leaflet was restrictive. The left atrium $(6.2 / 5.5 \mathrm{~cm})$ and left ventricle $(7.2 / 4.9 \mathrm{~cm})$ were enlarged, but EF was good (58\%). Carpentier-Edwards Physio Annuloplasty Ring 28 with 2 double Gore-Tex loops was used. A cleft of the A2 segment was sutured.

The third patient was a 74-year-old woman with paroxysmal atrial fibrillation and mitral regurgitation defined as I, II according to Carpentier's functional classification. Anterior leaflet prolapse and two clefts of the posterior leaflet (P1/P2 and P2/P3) were visualized during preoperative echocardiographic examination. Severe tricuspid valve regurgitation and severe pulmonary hypertension (SPAP $75 \mathrm{~mm} \mathrm{Hg}$ ) were co-existing. The left atrium was enlarged $(6.7 / 5.5 \mathrm{~cm})$. Left ventricle diameter was within normal limits, with good EF (65\%). Three double Gore-Tex loops were implanted to the A1, A2 and A3 segments. Leaflet clefts P1/ P2 and P2/P3 were sutured. The mitral repair was completed with CG Future Annuloplasty Mitral Valve Ring 28. Tricuspid valve annuloplasty with Carpentier-Edwards Classic Tricuspid Annuloplasty Ring $30 \mathrm{~mm}$ was also conducted.

All 3 patients also underwent transesophageal echocardiography (TEE), performed as a standard examination, evaluating the mid-term results of surgical mitral valve repair. Results of both examinations, TEE and CTA, were compared.

\section{Results}

Computed tomography angiography was performed at 20-24 months after the surgery (Figs. 1-4). Long-axis views, reconstructed during mid-systole, seemed to be the most valuable. Good quality cardiac images, precisely presenting the mitral valve complex with its constituents, were obtained in the case of patients without obesity, with a relatively small anterior-posterior thorax dimension, with 


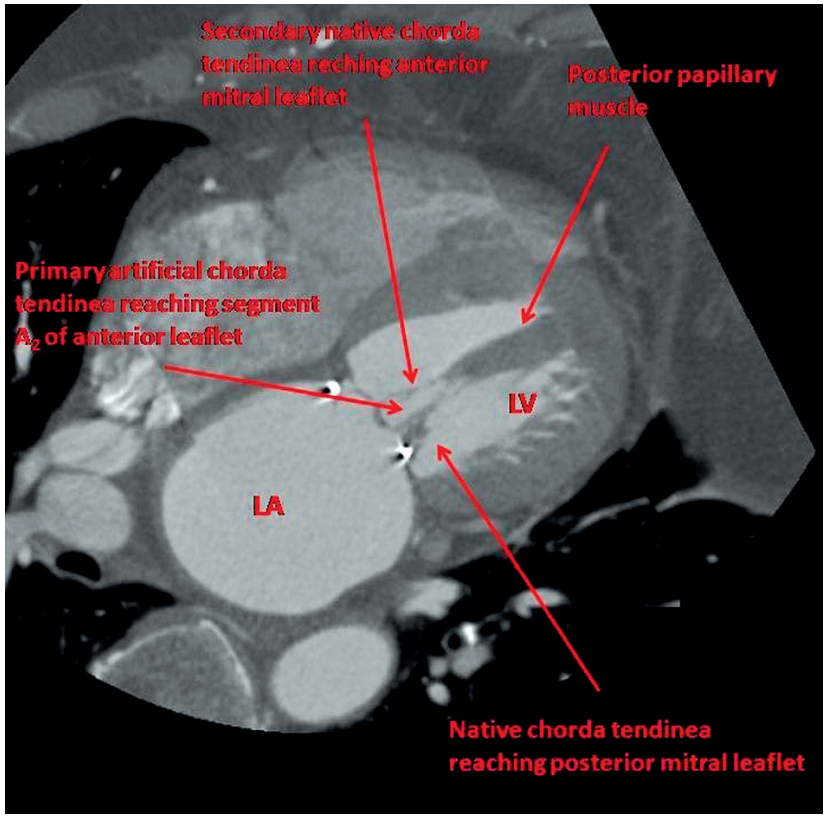

Fig. 2. Four-chamber cardiac view of the first patient. Good view of the coaptation at the mid-systolic phase. Implanted annuloplasty ring is seen

LV - left ventricle, LA - left atrium.

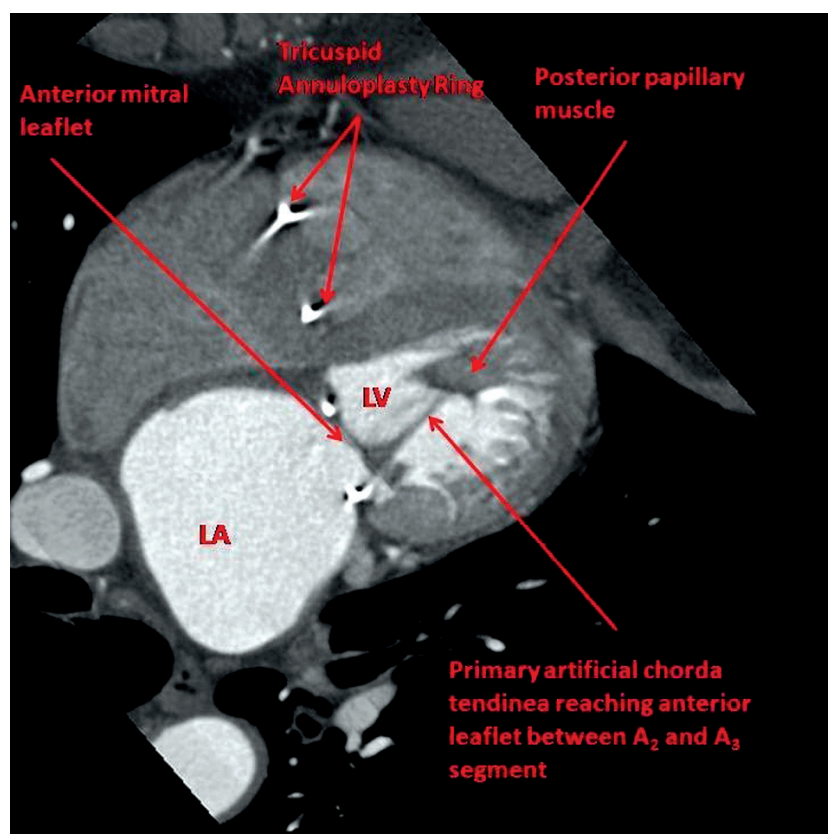

Fig. 4. Third patient. Tricuspid and mitral annuloplasty ring is seen. Descending aorta is visible. Coaptation line confirms good midterm result of the mitral valve repair, primary artificial chordae between A2/A3 segments

sinus and slow heart rhythm, and quite good left ventricle contractility (all 3 presented patients met the mentioned criteria). Evaluation of mitral valve anatomy included morphologic features of the mitral valve, presence of calcifications, fibrosis or thickening. The evaluation of mitral valve geometry included chordal insertion points and the coaptation point, compared with the mitral annulus plane, and

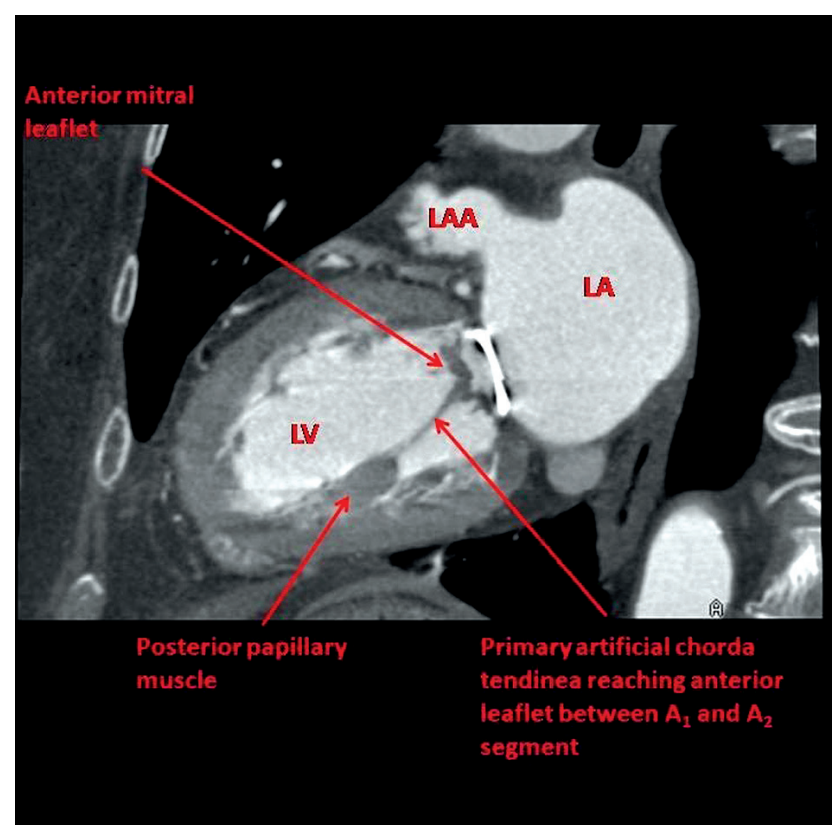

Fig. 3. Good visualization of the mitral valve apparatus in the third patient. Left atrial appendage can be assessed in order to exclude thrombus. Examination of the surrounding structures, especially the pericardial sac, can be evaluated after the surgery

Tab. I. Left ventricle and left atrium parameters evaluated with computed tomography angiography (CTA) after neochordal mitral valve repair over mid-term follow-up

\begin{tabular}{lccccc} 
Patient & LVEF (\%) & EDV [ml] & ESV [ml] & SV [ml] & LA vol. [ml] \\
\hline 1 & 54 & 138 & 63 & 75 & 140 \\
\hline 2 & 57 & 172 & 73 & 99 & 214 \\
\hline 3 & 62 & 137 & 51 & 86 & 115 \\
\hline
\end{tabular}

LVEF - left ventricle ejection fraction, EDV - end-diastolic volume, ESV - endsystolic volume, SV - stroke volume, LA vol. - left atrium volume.

papillary muscle locations. Primary and secondary native chordae tendineae and artificial chordae were visualized. Myocardial contractility was also assessed. From our examined patients only the third one presented slight mitral regurgitation, also confirmed by TEE. Diameters of cardiac chambers were also assessed (Tab. I). Clinically all patients presented functional NYHA class I.

\section{Discussion}

Nowadays mitral valve repair, in degenerative or even in rheumatic mitral regurgitation, is considered as a safe procedure, with confirmed long-term durability [4]. The period free from reoperation reaches $95-98 \%$ in a 10 -year followup [4]. In our patients neochordal repair, without partial leaflets resection, gave satisfactory results, as confirmed by previous authors [5].

The role of additional supplementary cardiac imaging examinations is still increasing. Computed tomography angiography is not only a negative predictor of coronary artery atherosclerosis, but is also indicated to evaluate the anatomy of the left atrium and pulmonary veins, and ex- 
clude thrombus before surgical ablation. It allows for evaluation of the surrounding cardiac structures. Great vessels can also be clearly visualized during examination. However, it demands some experience in assessing cardiac pathologies from the radiologist. Therefore, it can have multimodal application before planning interventions on the mitral valve, especially when echocardiography does not provide exact images. Our study proves that it can be successfully used after an operation, and the results should be compared with preoperative CTA images, if performed, to increase the value of this imaging method. Our experience shows that it cannot be performed as a standard examination in all types of patients to evaluate the results of neochordal mitral repair. It seems that patients without obesity, with sinus rhythm, and quite good EF are suitable patients, in whom CTA provides informative mitral images with relatively safe examination parameters.

Wang et al. [6] presented wide possibilities of CTA imaging, complemented by finite element modeling of the mitral valve complex with HyperMesh software. It allowed very precise description of the mitral valve and provided many significant parameters, important for performing a successful surgical mitral valve repair (coaptation depth, coaptation length, annular circumference).

Cardiac magnetic resonance (CMR) in mitral regurgitation has limited indications. In the case of a poor acoustic window or contraindications to TEE, it can be especially helpful for assessing the volume and function of the left ventricle, or evaluation of the severity of valvular regurgitation [1]. Chaikriangkrai et al. [7] used CMR to assess the presence of myocardial fibrosis as a negative predictor after mitral repair.

Well-known disadvantages of CTA are radiation and contrast administration. Importantly, there is no possibility of transvalvular gradient measurement. However, in the case of significant mitral regurgitation planimetric measurements of the regurgitant orifice area can be used for quantitative evaluation of the mitral regurgitation severity. Poor temporal resolution disqualifies this method from routine usage, but evaluation of mid-term results of neochordal mitral repair in a selected group of patients can be performed with satisfactory quality.

According to our knowledge, this is the first report of imaging results of the surgical mitral valve sparing procedure with CTA.

\section{Conclusions}

Contrast material-enhanced ECG-gated CT angiography used in patients after mitral valve repair with Gore-Tex neochordae allows one to obtain satisfactory mitral valve images, especially during mid-systole, and evaluate mid-term results of the surgery in selected patients. CTA provides excellent visualization of artificial chordae with identification of the sutures' location and coaptation plane assessment.

\section{Disclosure}

Authors report no conflict of interest.

\section{References}

1. Rużyłło W, Hryniewiecki T, Gąsior Z. Wady serca. Medical Tribune Polska Sp. z o.o., Warszawa 2013.

2. Enriquez-Sarano M, Akins CW, Vahanian A. Mitral regurgitation. Lancet 2009; 373: 1382-1394.

3. Ryan R, Abbara S, Colen RR, Arnous S, Quinn M, Cury RC, Dodd JD. Cardiac valve disease: spectrum of findings on cardiac 64-MDCT. AJR Am J Roentgenol 2008; 190: W294-wW303.

4. Dillon J, Yakub MA, Kong PK, Ramli MF, Jaffar N, Gaffar IF. Comparative longterm results of mitral valve repair in adults with chronic rheumatic disease and degenerative disease: is repair for "burnt-out" rheumatic disease still inferior to repair for degenerative disease in the current era? J Thorac Cardiovasc Surg 2014; 149: 771-777.

5. Nigro JJ, Schwartz DS, Bart RD, Bart CW, Lopez BM, Cunningham MJ, Barr ML, Bremner RM, Haddy SM, Wells WJ, Starnes VA. Neochordal repair of the posterior mitral leaflet. J Thorac Cardiovasc Surg 2004; 127: 440-447.

6. Wang $\mathrm{Q}$, Sun W. Finite element modeling of mitral valve dynamic deformation using patient-specific multi-slices computed tomography scans. Ann Biomed Eng 2013; 41: 142-153.

7. Chaikriangkrai K, Lopez-Mattei JC, Lawrie G, Ibrahim H, Quinones MA, Zoghbi W, Little SH, Shah DJ. Prognostic value of delayed enhancement cardiac magnetic resonance imaging in mitral valve repair. Ann Thorac Surg 2014; 98: 1557-1563. 